\title{
TERAPI AFEKTIF MEDIA DIGITAL TERHADAP PROKRASTINASI AKADEMIK PADA TUGAS AKHIR DAN SKRIPSI MAHASISWA DI ERA PANDEMI COVID-19
}

\author{
Fani Juliyanto Perdana', Abas Hidayat ${ }^{1}$, Varidlo Fuad ${ }^{2 *}$ \\ Sekolah Tinggi Ilmu Kesehatan Cirebon ${ }^{1}$, IAIN Syekh Nurjati Cirebon ${ }^{2 *}$ \\ fanijuliyanto@gmail.com, abasstikescirebon@gmail.com,v.fuad212@gmail.com
}

\begin{abstract}
ABSTRAK
Tujuan dari penelitian ini adalah untuk mengetahui pengaruh pemanfaatan terapi afektif media digital pada self-control, self-esteem, dan self-efficacy terhadap tindakan prokrastinasi akademik yang dilakukan mahasiswa saat melaksanakan Tugas Akhir atau Skripsi di era pandemic covid-19. Penelitian yang dilakukan adalah penelitian experimen melalui quasi experimental design. Seluruh mahasiswa aktif di lingkungan Fakultas UAD IAIN Syekh Nurjati Cirebon yang sedang menyusun karya tulis ilmiah berbentuk Tugas Akhir dan Skripsi yang berjumlah 320 mahasiswa merupakan populasi pada penelitian ini. Sampel diambil melalui simple random sampling, antara kelompok eksperimen (160 mahasiswa) dan kelompok kontrol (160 mahasiswa). Hasil penelitian dilakukan dengan menggunakan uji Mann Whitney untuk melihat hasil uji hipotesis yang menyatakan bahwa mahasiswa yang sedang melaksanakan tugas akhir dan skripsi, yang dibantu dengan penggunaan terapi afektif media digital terbukti dapat memberikan pengaruh yang signifikan secara parsial pada self-control $(0,000)$, selfesteem $(0,000)$, dan self-efficacy $(0,032)$ dengan taraf signifikan $5 \%$ terhadap prokrastinasi akademik di era pandemic covid-19.
\end{abstract}

Kata kunci: terapi afektif media digital; self-control; self-esteem; self-efficacy; prokrastinasi akademik

\section{ABSTRACT}

This study aims to determine the effect of using digital media affective therapy on self-control, self-esteem, and self-efficacy on academic procrastination by students when carrying out their final project or thesis in the era of pandemic COVID-19. This research is an experimental study using a quasi-experimental design. The research population is all active students in the Faculty of UAD IAIN Syekh Nurjati Cirebon who are currently compiling scientific papers in the form of final projects and thesis with a total of 320 students. The sample in this study was taken by simple random sampling, namely two classes which were divided into an experimental group of 160 students and a control group of 160 students. The results showed that students who were carrying out their final project and thesis assisted by the use of digital media affective therapy were proven to have a partially significant effect on self-control (0.000), self-esteem (0.000), and self-efficacy (0.032). from the results of hypothesis testing conducted with the Mann Whitney test with a significant level of $5 \%$ on academic procrastination in the era pandemic covid-19.

Keywords: digital media affective therapy; self-control; self-esteem; self-efficacy; academic procrastination 


\section{A. PENDAHULUAN}

Salah satu sektor strategis yang terdampak pandemic covid-19 adalah pelaksanaan proses pendidikan. Dari pertemuan tatap muka menjadi pembelajaran via daring saat covid-19 di Indonesia untuk mengurangi mobilitas orang dari satu tempat ke tempat yang lain (Pakpahan \& Fitriani, 2020). Kecenderungan pemanfaatan teknologi di dalam dunia pendidikan terutama pada era pandemic covid-19 seperti ini dibutuhkan untuk dapat mewujudkan proses pembelajaran yang efektif. Namun, setelah beberapa bulan penerapan metode daring pada proses pembelajaran terdapat hasil survey yang menghasilkan sebuah kesimpulan bahwa hasil belajar belum dapat ditingkatkan secara efektif melalui kegiatan belajar online (Simatupang et al., 2020).

Tidak terkecuali pendidikan tinggi, syarat mahasiswa dapat dinyatakan lulus wajib menyelesaikan tugas akhir dan skripsi (Menristekdikti, 2015) untuk mengkonstruksikan pemikirannya dalam menulis suatu karya tulis ilmiah (Etika et al., 2016) yang dituntut bertanggungjawab, disiplin, dan konsisten sehingga mampu menyelesaikan tugas akhir dan skripsi. Alih-alih mahasiswa dapat belajar di rumah secara efektif, adanya kemudahan game online hingga media sosial dapat berimbas menghilangkan fokus utama mahasiswa dalam menyelesaikan tugas akhir dan skripsi yang disebut dengan prokrastinasi akademik.

Prokrastinasi akademik menjadi penting untuk diteliti karena menghambat mahasiswa untuk menyelesaikan jenjang pendidikan tingginya, oleh karena itu melalui terapi afektif pada media digital diharapkan dapat membantu mahasiswa untuk efektif dalam menjalankan masa studinya terutama dalam hal kewajibannya untuk membuat tugas akhir maupun skripsi. Unsur kebaharuan pada penelitian ini adalah menawarkan terapi afektif yang dapat meningkatkan self-control, selfesteem, dan self-efficacy melalui media digital untuk mengurangi kecenderungan prokrastinasi akademik pada tugas akhir dan skripsi yang dilakukan oleh mahasiswa.

\section{Terapi Afektif Media Digital}

Secara etimologis terapi afektif media digital merupakan gabungan dari empat suku kata yang melengkapi satu dengan lainnya. Secara definisi media digital adalah format konten yang dapat diakses oleh perangkat-perangkat digital. Untuk 
penelitian kali ini, media digital yang digunakan adalah dengan menggunakan youtube. Pemilihan tersebut didasarkan karena kemudahan dalam mengakses youtube yang dapat dilakukan dimanapun dan kapanpun sehingga tidak terbatas oleh ruang dan waktu juga sudah familiar dikenal khalayak umum. Pengunaan media digital untuk dapat menguatkan aspek afektif mahasiswa dalam menyelesaikan tugas akhir dan skripsi yang meliputi self-control, self-esteem, selfefficacy mengikuti prinsip-prinsip terapi realita yang bertujuan untuk memenuhi kebutuhan psikologis mereka dengan cara yang bertanggung jawab (Adiputra, 2016). Pendekatan terapi realita melalui The WDEP System yaitu wants, direction \& doing, evaluation, planing (Adiputra \& Wahyu NES, 2015).

\section{Kontrol Diri (Self-Control)}

Kontrol Diri (self-control) adalah kemampuan seseorang untuk mengontrol atau mengubah respon dari dalam dirinya untuk menghindarkan diri dari perilaku yang tidak diharapkan dan mengarahkan dirinya pada sesuatu yang ingin digapai (Ursia et al., 2013). Semakin tinggi tingkat penguasaan self-control pada diri mahasiswa, maka semakin baik mahasiswa tersebut untuk tidak menunda-nunda dalam menyelesaikan tugas yang sudah menjadi kewajibannya, terlebih pada jenis tugas yang menuntut tingkat kemandirian tinggi seperti tugas akhir maupun skripsi (Ursia et al., 2013).

Menurut Tangney, Baumeister, dan Boone mengusulkan bahwa self control terdiri dari lima aspek berikut (Ursia et al., 2013): (1) self-discipline adalah suatu kemampuan kemampuan invidu dalam melakukan disiplin diri; deliberate/nonimpulsive adalah kecenderungan individu untuk tidak tergesa-gesa dalam melakukan suatu hal, bersifat hati-hati, dan penuh pertimbangan; (3) healty habits adalah kebiasaan yang menyehatkan sebagai hasil kemampuan individu dalam mengatur pola prilakunya; (4) work ethic berkaitan pada penilaian indvidu berdasarkan kemampuan dirinya pada saat melaksanakan pekerjaan terhadap sistem etika yang ada; (5) reliability merupakan kemampuan individu dalam melaksanakan apa yang sudah direncanakan sesuai dengan tujuan yang ingin diraih.

\section{Harga diri (self-esteem)}


Harga diri (self-esteem) merupakan aspek penting terhadap pembentukan kepribadian seseorang yang juga memberikan dampak yang luas pada sikap dan perilakunya (Srisayekti \& Setiady, 2015). Semakin seseorang tidak dapat menghargai dirinya sendiri secara layak, maka sulit baginya untuk dapat mengahragai orang lain.

Hasil pada penelitian sebelumnya menyatakan adanya keterkaitan antara selfesteem dengan prestasi belajar membuktikan bahwa tema ini masih menjadi perdebatan yang menarik. Misalnya, dari hasil uji hipotesis dinyatakan terdapat hubungan antara harga diri (self-esteem) dengan prokrastinasi akademik pada siswa Madrasah Aliyah Negeri di Malang Raya (Putrisari et al., 2017). Ahli lainya menyatakan tidak ada korelasi antara kedua variabel, atau jika ada, korelasinya sangat kecil. Ahli lainnya menyatakan bahwa self-esteem baru dapat mempengaruhi prokrastinasi akademik, jika terdapat variabel antara lain yang ikut diteliti. Bahkan beberapa ahli menyatakan, bukanlah self-esteem yang mempengaruhi prokrastinasi akademik, namun prokrastinasi akademiklah yang mempengaruhi self-esteem. Perdebatan yang banyak mengenai keterkaitan antara self-esteem dengan prokrastinasi akademik, membuat peneliti tertarik untuk meneliti lebih lanjut keterkaitan antara self-esteem dengan prokrastinasi akademik yang meliputi aspek kekuatan (power), keberartian (significance), kebijakan (viture), dan kompetensi (competence).

\section{Kehandalan Diri (Self-Efficacy)}

Self-efficacy adalah bentuk penilaian diri, bisa tidaknya individu melakukan hal yang baik, tepat, dan dapat meyelesaikan suatu hal sesuai dengan syarat yang ditentukan. Self-efficacy menggambarkan penilaian kemampuan diri (Putrisari et al., 2017). Self-efficacy juga merupakan sebagai evaluasi seseorang mengenai kemampuan atau kompetensi dirinya untuk melakukan tugas, mencapai suatu tujuan dan mengatasi hambatan.

Pada penelitian terdahulu diperoleh bahwa self-efficacy berpengaruh secara signifikan terhadap prokrastinasi akademik yang dilakukan oleh siswa (Alwisol, 2012). Dari apa yang sudah dijelaskan pada penelitian sebelumnya, pembeda pada kegiatan yang akan dilakukan oleh peneltian ini terletak pada perlunya melihat self- 
efficacy tidak hanya pada mahasiswa yang berpresetasi tetapi juga secara umum, karena tingkat self-efficacy yang dimiliki antara satu orang dengan orang lain berbeda ditinjau dari tiga dimensi (Ghufron \& Rini, 2010): (1) berkaitan dengan tingkat kesulitan yang diyakini dapat diselesaikan (dimensi tingkat/magnitude/level); (2) berkaitan tentang apa yang menjadi kekuatan maupun kelemahan sesuai dengan kompetensi yang dimiliki (dimensi strength); (3) berkaitan dengan keyakinan seseorang yang dihadapakan pada segala macam aktivitas dan situasi.

\section{Prokrastinasi Akademik}

Menurut Solomon dan Rothblum prokrastinasi sendiri merupakan suatu kecenderungan perilaku menunda-nunda baik untuk memulai maupun menyelesaikan kinerja secara keseluruhan dengan melakukan aktivitas lain yang tidak berguna, sehingga kinerja menjadi terhambat, tidak pernah menyelesaikan tugas tepat waktu, serta sering terlambat dalam menghadiri pertemuan-pertemuan (Alwisol, 2012). Sedangkan prokrastinasi akademik ialah prokrastinasi yang terjadi pada area akademik, dimana skripsi merupakan salah satu area akademik terpenting karena menjadi salah satu syarat bagi mahasiswa untuk memperoleh gelar S1 (Ursia et al., 2013).

Janssen dan Carton (Ursia et al., 2013) mengusulkan lima hal yang sering dikaitkan dengan tingginya kecenderungan prokrastinasi, yaitu rendahnya kontrol diri (self-control), self-consciousness, self-esteem, dan self-efficacy, serta adanya kecemasan sosial. Di antara kelima hal tersebut, yang dijadikan fokus pada penelitian ini adalah self-control, self-esteem, dan self-efficacy. Berdasarkan penjelasan sebelumnya peneliti ingin mengajukan kegiatan uji coba (eksperimen) antara kelompok kontrol dengan kelompok eksperimen mengenai adakah pengaruh terapi afektif media digital terhadap prokrastinasi yang dilakukan oleh mahasiswa (self control, self esteem, dan self efficacy) terutama pada saat melaksanakan tugas akhir dan skripsi.

\section{B. METODE PENELITIAN}

Jenis penelitian yang digunakan adalah penelitian eksperimen dengan pendekatan kuantitatif. Penelitian ini dimaksudkan untuk melihat akibat perlakuan 
penggunaan terapi afektif media digital terhadap prokratinasi tugas akhir maupun skripsi yang dilakukan oleh mahasiswa (self control, self esteem, dan self efficacy).

Desain penelitian yang digunakan yaitu dengan menggunakan randomized pre test-post test control group design (Sugiyono, 2009) yaitu dengan menyediakan 2 kelompok antara kelompok eksperimen dan kelompok kontrol. Penelitian ini juga melakukan pre-test maupun post-test, baik pada kelas kontrol maupun kelas eksperimen untuk mengetahui kemampuan self control, self esteem, dan self efficacy terhadap prokrastinasi tugas akhir maupun skripsi yang dilakukan oleh mahasiswa semester akhir. Khusus untuk kelompok eksperimen diberikan perlakuan berupa terapi afektif.

Populasi penelitian adalah seluruh mahasiswa aktif di lingkungan Fakultas UAD IAIN Syekh Nurjati Cirebon dan sedang menyusun karya tulis ilmiah berbentuk tugas akhir dan skripsi dengan jumlah 320 mahasiswa. Sampel penelitian dilakukan dengan menggunakan simple random sampling karena seluruh anggota populasi memiliki probabilitas yang sama untuk dipilih. Pengumpulan data dalam penelitian dengan menggunakan angket/kuesinoer sebagai data primer juga data sekunder yang diperoleh dari bagian administrasi akademik IAIN Syekh Nurjati Cirebon. Kedua instrumen tersebut dilakukan baik oleh kelompok kelas eksperimen maupun kelompok kelas kontrol pada saat pre-test maupun post-test.

\section{Uji Validitas dan Realibitlas Instrumen}

Uji validitas yang dilakukan dalam penelitian ini dilakukan dengan dua tahapan. Pertama, dengan menggungakan validitas ahli untuk meminta pertimbangan dari para ahli (terkait bahasa dan subtansi). Kedua, melakukan validitas melalui uji coba instrumen dengan responden yang memiliki karakteristik yang sama dengan responden yang akan diteliti. Uji coba instrumen diujicobakan pada 50 mahasiswa semester akhir yang sedang menyusun tugas akhir atau skripsi di Fakultas Ilmu Tarbiyah dan Keguruan (FITK) IAIN Syekh Nurjati Cirebon. Pemilihan lokasi uji coba instrumen atas dasar memiliki karakterisktik yang sama dengan lokasi penelitian yaitu Fakultas UAD IAIN Syekh Nurjati Cirebon. Uji validitas ini menggunakan rumus product moment dari Pearson, yaitu sebagai berikut. 


$$
r_{x y}=\frac{(n)\left(\sum X Y\right)-\left(\sum X\right)\left(\sum Y\right)}{\sqrt{\left\{\left(n \cdot \sum X^{2}\right)-\left(\sum X\right)^{2}\right\}\left\{\left(n \cdot \sum Y^{2}\right)-\left(\sum Y\right)^{2}\right\}}}
$$

Keterangan:

$r_{x y} \quad=$ koefisien korelasi antara $\mathrm{x}$ dan $\mathrm{y}$

$n \quad=$ jumlah responden

$\sum X \quad=$ jumlah skor butir

$\sum Y \quad=$ total dari jumlah skor yang diperoleh tiap responden

$\sum X^{2} \quad=$ jumlah dari kuadrat butir

$\sum Y^{2} \quad=$ total dari kuadrat jumlah skor yang diperoleh tiap responden

$\sum X Y \quad=$ jumlah hasil perkalian antara skor butir angket dengan jumlah skor yang diperoleh tiap responden (Arikunto, 2010).

Setelah melalui proses analisis maka dapat diketahui, jika $r_{\text {hitung }} \geq 0,30$ maka butir pernyataan tersebut valid. Jika $\mathbf{r}_{\text {hitung }}<0,30$ maka butir pernyataan tersebut tidak valid (Sugiyono, 2009). Dalam penelitian ini analisisnya menggunakan progam SPSS (Statistical Program for Social Science) for windows. Dengan ketentuan jika p hit > 0,05 maka butir soal dinyatakan tidak valid.

Pada hasil uji coba variabel self-control terhadap Prokrastinasi Akademik pada tugas akhir atau skripsi mahasiswa yang awalnya memiliki 20 butir soal setelah dianalisis terdapat 3 soal yang gugur pada nomor 10, 13, dan 20 sehingga butir soal yang dinyatakan valid pada variabel self-control berjumlah 17 butir soal. Selanjutnya, Pada hasil uji coba variabel self-esteem terhadap Prokrastinasi Akademik pada tugas akhir atau skripsi mahasiswa yang awalnya memiliki 16 butir soal setelah dianalisis terdapat 1 soal yang gugur pada nomor 5 sehingga butir soal yang dinyatakan valid pada variabel self-esteem berjumlah 15 butir soal. Terakhir, untuk hasil uji coba variabel self-efficacy terhadap Prokrastinasi Akademik pada tugas akhir atau skripsi mahasiswa yang awalnya memiliki 12 butir soal setelah dianalisis terdapat 2 soal yang gugur pada nomor 1 dan 12 sehingga butir soal yang dinyatakan valid pada variabel self-efficacy berjumlah 10 butir soal. Berikut adalah rekap hasil uji validitas pada instrumen penelitian.

Tabel 1. Hasil Uji Validitas Instrumen Penelitian

\begin{tabular}{|c|c|c|c|c|}
\hline Variabel & $\begin{array}{c}\text { Jumlah } \\
\text { butir } \\
\text { sebelum } \\
\text { uji coba }\end{array}$ & $\begin{array}{l}\text { Jumlah } \\
\text { butir } \\
\text { gugur }\end{array}$ & $\begin{array}{l}\text { No. butir } \\
\text { gugur }\end{array}$ & $\begin{array}{c}\text { Jumlah } \\
\text { butir valid }\end{array}$ \\
\hline 1. Self-Control & 20 & 3 & 10,13 dan 20 & 17 \\
\hline 2. Self-Esteem & 16 & 1 & 5 & 15 \\
\hline 3. Self-Efficacy & 12 & 2 & 1 dan 12 & 10 \\
\hline
\end{tabular}




\begin{tabular}{|c|c|c|c|c|}
\hline Jumlah & 48 & 6 & & 42 \\
\hline
\end{tabular}

Setelah melakkan uji validitas maka dilanjutkan dengan, uji reliabilitas. Dalam penelitian ini, uji reliabilitas instrumen digunakan metode alpha. Cronbach alpha dapat digunakan untuk menguji reliabilitas instrumen skala Likert rumusnya sebagai berikut.

$$
\alpha=\left(\frac{\mathrm{k}}{(\mathrm{k}-1)}\right)\left(1-\frac{\sum \mathrm{S}_{\mathrm{i}}^{2}}{\mathrm{~s}_{\mathrm{i}}^{2}}\right)
$$

Keterangan :

$\mathrm{K}=$ Jumlah item

$\Sigma \mathrm{S}_{\mathrm{i}}^{2}=$ Jumlah varians skor total

$\mathrm{S}^{2}{ }_{\mathrm{i}}=$ Varians responden untuk item ke $\mathrm{i}$

Pedoman yang digunakan untuk menentukan tinggi rendah reliabilitas instrumen berdasarkan (Sugiyono, 2009). Instrumen dikatakan reliabel jika $\alpha \geq 0,60$, jika $\alpha<0,60$, maka instrumen tidak reliabel. Analisa reliabilitas penelitian ini dilakukan dengan menggunakan progam SPSS (StatisticalProgram for Social Science) for windows. Hasil perhitungan dapat dilihat pada tabel 5 .

Tabel 2. Hasil Uji Reliabilitas Instrumen Penelitian

\begin{tabular}{cccc}
\hline & Variabel & Koefisien Alpha & Interpretasi \\
\hline 1. & Self-Control & 0,857 & Tinggi \\
2. & Self-Esteem & 0,837 & Tinggi \\
3. & Self-Efficacy & 0,806 & Tinggi \\
\hline
\end{tabular}

Dari tabel 2 dapat diketahui bahwa pertama, analisis hasil uji coba variabel selfcontrol terhadap Prokrastinasi Akademik pada tugas akhir atau skripsi mahasiswa diperoleh koefisien aplha 0,857 hal ini menunjukkan bahwa instrumen tersebut memilki reliabilitas yang tinggi. Kedua, analisis hasil uji coba variabel self-esteem terhadap Prokrastinasi Akademik pada tugas akhir atau skripsi mahasiswa diperoleh koefisien alpha 0,837 yang menunjukkan bahwa instrumen tersebut memilki reliabilitas yang tinggi. Ketiga, analisis hasil uji coba variabel self-efficacy terhadap Prokrastinasi Akademik pada tugas akhir atau skripsi mahasiswa diperoleh koefisien alpha 0,806 yang menunjukkan bahwa instrumen tersebut juga memilki reliabilitas yang tinggi. Berdasarkan hasil tersebut kedua instrumen ini mempunyai kehandalan untuk mengukur variabel tersebut.

\section{HASIL DAN PEMBAHASAN}

\section{Data Deskriptif Self-Control pada Kelompok Kontrol}


Data pre-test kelompok kontrol pada variabel self-control terkait

prokrastinasi akademik digambarkan melalui diagram distribusi sebagai berikut:

Gambar 1. Pre-Test Self-Control Terkait

Prokrastinasi Akademik Pada Kelompok

Kontrol

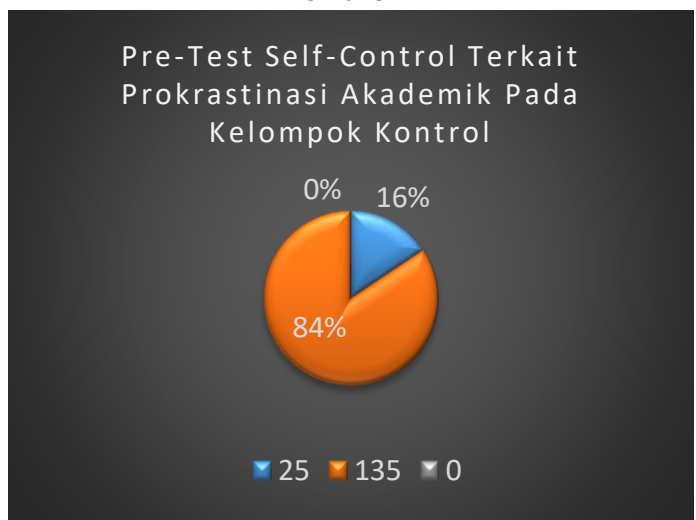

Berdasakan gambar 1 di samping menunjukkan bahwa tingkat self-control mahasiswa yang sedang mengerjakan tugas akhir maupun skripsi pada kelompok kontrol sebagian besar berada dalam kategori Sedang yaitu 135 mahasiswa $(84 \%)$ dan Tinggi yaitu 25 mahasiswa $(16 \%)$ dari total 160 mahasiswa yang terdapat di kelompok kontrol.

Data post-test kelompok kontrol pada variabel self-control terkait prokrastinasi akademik digambarkan melalui diagram distribusi sebagai berikut:

Gambar 2. Post-Test Self-Control Terkait

Prokrastinasi Akademik Pada Kelompok

Kontrol

Post-Test Self-Control Terkait Prokrastinasi Akademik Pada Kelompok Kontrol

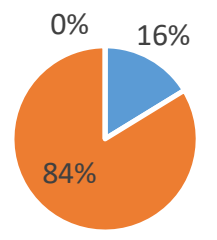

$-26=134=0$
Berdasakan gambar 2 di samping menunjukkan bahwa tingkat self-control mahasiswa yang sedang mengerjakan tugas akhir maupun skripsi pada kelompok kontrol sebagia besar berada dalam kategori Sedang yaitu 134 mahasiswa (84\%) dan Tinggi yaitu 26 mahasiswa (16\%) dari total 160 mahasiswa yang terdapat di kelompok kontrol.

\section{Data Deskriptif Self-Control pada Kelompok Eksperimen}

Data pre-test kelompok eksperimen pada variabel self-control terkait prokrastinasi akademik digambarkan melalui diagram distribusi sebagai berikut:

Gambar 3. Pre-Test Self-Control Terkait Prokrastinasi Akademik Pada Kelompok Eksperimen
Berdasakan gambar 3 di samping menunjukkan bahwa tingkat self-control mahasiswa yang sedang mengerjakan tugas akhir maupun skripsi pada kelompok eksperimen sebagia besar berada dalam kategori Sedang yaitu 156 mahasiswa $(98 \%)$ dan Tinggi yaitu 4 


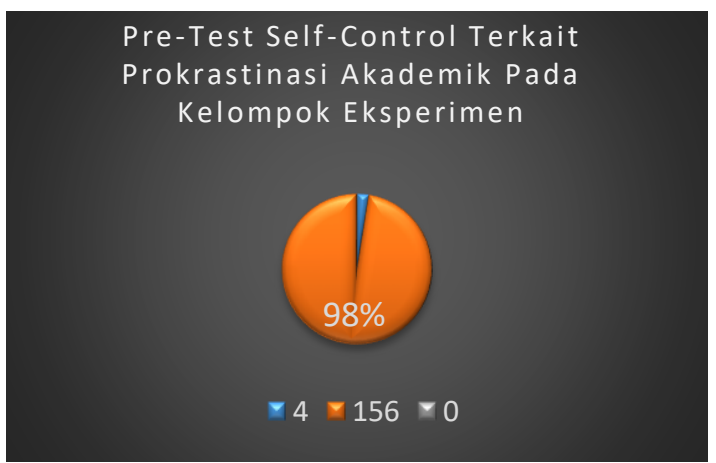

mahasiswa $(3 \%)$ dari total 160 mahasiswa yang terdapat di kelompok eksperimen.

Data post-test kelompok eksperimen pada variabel self-control terkait prokrastinasi akademik digambarkan melalui diagram distribusi sebagai berikut:

Gambar 4. Post-Test Self-Control Terkait Prokrastinasi Akademik Pada Kelompok Eksperimen

Post-Test Self-Control Terkait Prokrastinasi Akademik Pada Kelompok Eksperimen

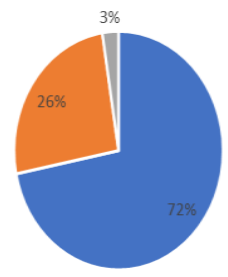

$115=41=4$
Berdasakan gambar 4 di samping menunjukkan bahwa tingkat self-control mahasiswa yang sedang mengerjakan tugas akhir maupun skripsi pada kelompok eksperimen sebagia besar berada dalam kategori Tinggi yaitu 115 mahasiswa (72\%), Sedang yaitu 41 mahasiswa (26\%), dan Rendah yaitu 4 mahasiswa $(3 \%)$ dari total 160 mahasiswa yang terdapat di kelompok eksperimen.

\section{Data Deskriptif Self-Esteem ada Kelompok Kontrol}

Data pre-test kelompok kontrol pada variabel self-esteem terkait prokrastinasi akademik digambarkan melalui diagram distribusi sebagai berikut:

Gambar 5. Pre-Test Self-Esteem Terkait Prokrastinasi Akademik Pada Kelompok Kontrol

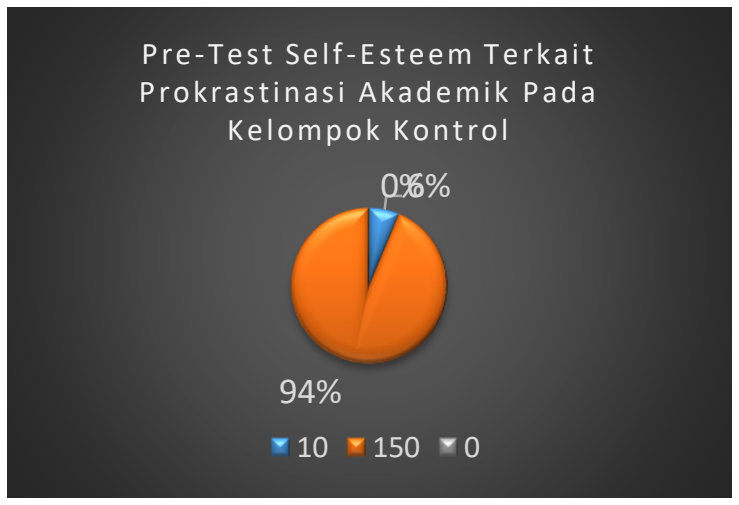

Berdasakan gambar 5 di samping menunjukkan bahwa tingkat self-esteem mahasiswa yang sedang mengerjakan tugas akhir maupun skripsi pada kelompok kontrol sebagia besar berada dalam kategori Sedang yaitu 150 mahasiswa (94\%) dan Tinggi yaitu 10 mahasiswa (6\%) dari total 160 mahasiswa yang terdapat di kelompok kontrol.

Data post-test kelompok kontrol pada variabel self-esteem terkait prokrastinasi akademik digambarkan melalui diagram distribusi sebagai berikut: 
Gambar 6. Post-Test Self-Esteem Terkait Prokrastinasi Akademik Pada Kelompok

Kontrol

Post-Test Self-Esteem Terkait Prokrastinasi Akademik Pada Kelompok Kontrol

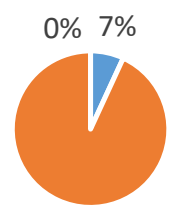

$93 \%$

- $11=149=0$

Berdasakan gambar 6 di samping menunjukkan bahwa tingkat self-esteem mahasiswa yang sedang mengerjakan tugas akhir maupun skripsi pada kelompok kontrol sebagia besar berada dalam kategori Sedang yaitu 149 mahasiswa (93\%) dan Tinggi yaitu 11 mahasiswa (7\%) dari total 160 mahasiswa yang terdapat di kelompok kontrol.

\section{Data Deskriptif Self-Esteem pada Kelompok Eksperimen}

Data pre-test kelompok eksperimen pada variabel self-esteem terkait prokrastinasi akademik digambarkan melalui diagram distribusi sebagai berikut:

Gambar 7. Pre-Test Self-Esteem Terkait

Prokrastinasi Akademik Pada Kelompok

Eksperimen

Pre-Test Self-Esteem Terkait Prokrastinasi Akademik Pada Kelompok Eksperimen

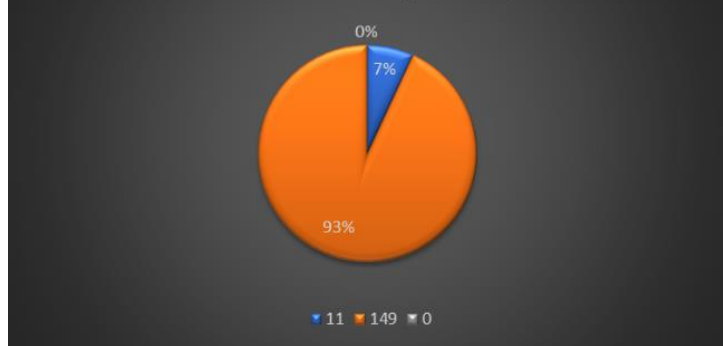

Berdasakan gambar 7 di samping menunjukkan bahwa tingkat self-esteem mahasiswa yang sedang mengerjakan tugas akhir maupun skripsi pada kelompok eksperimen sebagia besar berada dalam kategori Sedang yaitu 149 mahasiswa (93\%) dan Tinggi yaitu 11 mahasiswa $(7 \%)$ dari total 160 mahasiswa yang terdapat di kelompok eksperimen.

Data post-test kelompok eksperimen pada variabel self-esteem terkait prokrastinasi akademik digambarkan melalui diagram distribusi sebagai berikut:

Gambar 8. Post-Test Self-Esteem Terkait Prokrastinasi Akademik Pada Kelompok Eksperimen

Berdasakan gambar 8 di samping menunjukkan bahwa tingkat self-esteem mahasiswa yang sedang mengerjakan tugas akhir maupun skripsi pada kelompok eksperimen sebagia besar berada dalam kategori Sedang yaitu 142 mahasiswa (89\%) dan Tinggi yaitu 18 mahasiswa $(11 \%)$ dari total 160 
Post-Test Self-Esteem Terkait Prokrastinasi Akademik Pada Kelompok Eksperimen

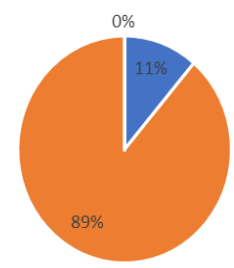

mahasiswa yang terdapat di kelompok eksperimen.

\section{Data Deskriptif Self-Efficacy pada Kelompok Kontrol}

Data pre-test kelompok kontrol pada variabel self-efficacy terkait prokrastinasi akademik digambarkan melalui diagram distribusi sebagai berikut:

Gambar 9. Pre-Test Self-Efficacy Terkait Prokrastinasi Akademik Pada Kelompok Kontrol

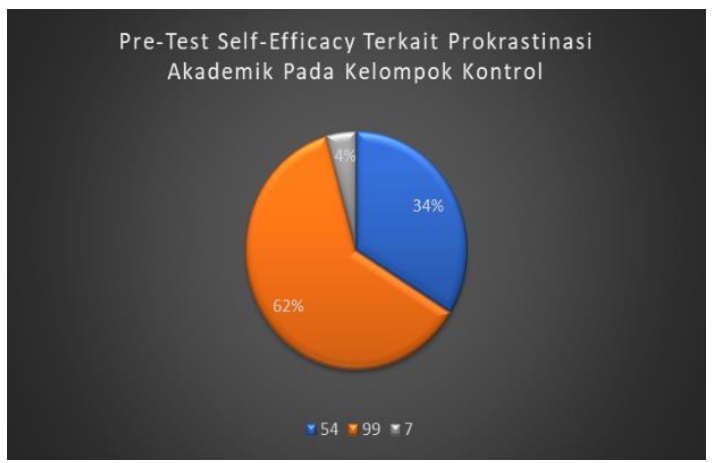

Berdasakan gambar 9 di samping menunjukkan bahwa tingkat self-efficacy mahasiswa yang sedang mengerjakan tugas akhir maupun skripsi pada kelompok kontrol sebagian besar berada dalam kategori Sedang yaitu 99 mahasiswa (62\%), Tinggi yaitu 54 mahasiswa (34\%), dan Rendah yaitu 7 mahasiswa (4\%) dari total 160 mahasiswa yang terdapat di kelompok kontrol.

Data post-test kelompok kontrol pada variabel self-efficacy terkait prokrastinasi akademik digambarkan melalui diagram distribusi sebagai berikut:

Gambar 10. Post-Test Self-Efficacy Terkait Prokrastinasi Akademik Pada Kelompok Kontrol

Post-Test Self-Efficacy Terkait Prokrastinasi Akademik Pada Kelompok Kontrol

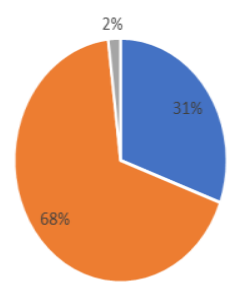

- 49 - $108=3$
Berdasakan gambar 10 di samping menunjukkan bahwa tingkat self-efficacy mahasiswa yang sedang mengerjakan tugas akhir maupun skripsi pada kelompok kontrol sebagian besar berada dalam kategori Sedang yaitu 108 mahasiswa (68\%), Tinggi yaitu 49 mahasiswa (31\%), dan Rendah yaitu 3 mahasiswa (2\%) dari total 160 mahasiswa yang terdapat di kelompok kontrol.

\section{Data Deskriptif Self-Efficacy pada Kelompok Eksperimen}

Data pre-test kelompok eksperimen pada variabel self-efficacy terkait prokrastinasi akademik digambarkan melalui diagram distribusi sebagai berikut: 
Gambar 11. Pre-Test Self-Efficacy Terkait Prokrastinasi Akademik Pada Kelompok Eksperimen

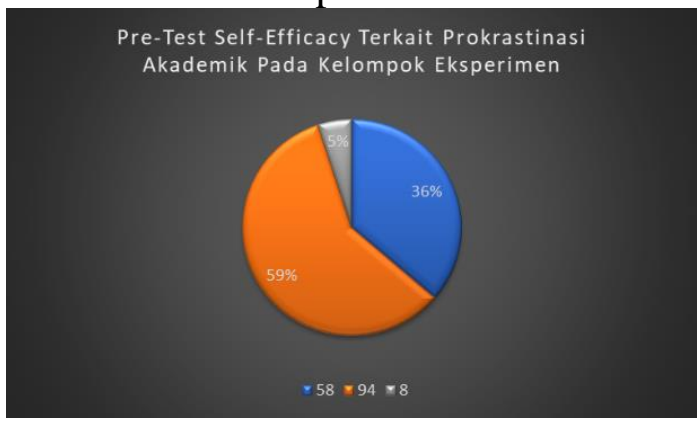

Berdasakan gambar 11 di samping menunjukkan bahwa tingkat self-efficacy mahasiswa yang sedang mengerjakan tugas akhir maupun skripsi pada kelompok eksperimen sebagian besar berada dalam kategori Sedang yaitu 94 mahasiswa (59\%), Tinggi yaitu 58 mahasiswa (36\%), dan Rendah yaitu 8 mahasiswa (5\%) dari total 160 mahasiswa yang terdapat di kelompok eksperimen.

Data post-test kelompok eksperimen pada variabel self-efficacy terkait prokrastinasi akademik digambarkan melalui diagram distribusi sebagai berikut:

Gambar 12. Post-Test Self-Efficacy Terkait Prokrastinasi Akademik Pada Kelompok Eksperimen

Post-Test Self-Efficacy Terkait Prokrastinasi Akademik Pada Kelompok Eksperimen

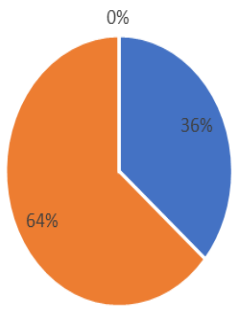

- $58=102=0$
Berdasakan gambar 12 di samping menunjukkan bahwa tingkat self-efficacy mahasiswa yang sedang mengerjakan tugas akhir maupun skripsi pada kelompok eksperimen sebagian besar berada dalam kategori Sedang yaitu 102 mahasiswa (64\%), dan Tinggi yaitu 58 mahasiswa (36\%), dari total 160 mahasiswa yang terdapat di kelompok eksperimen.

\section{Analisis Statistik}

\section{Uji Asumsi Statistik}

Berikut adalah uji asumsi statistik yang dilakukan sebelum melaksanakan uji hipotesis pada hasil analisis data, yang meliputi uji normalitas sebaran dan uji homogenitas variansi. Secara berurutan, baik hasil uji normalitas dan uji homogenitas dapat dilihat seperti di bawah ini:

a. Hasil uji normalitas dari masing-masing variabel penelitian, baik variabel pretest dan post-test kelas eksperimen maupun variabel pre-test dan post-test kelas kontrol mengacu pada salah satu dari dua kriteria yang ada. Kriteria pertama, data dianggap berdistribusi normal jika mempunyai nilai signifikansi lebih dari 0,05 (Sig.>0,05). Kriteria kedua, data dianggap berdistribusi tidak normal jika 
mempunyai nilai signifikasi kurang dari 0,05 (Sig.<0,05). Hasil uji normalitas pada setiap variabel penelitian (self-control, self-esteem, self-efficacy terhadap prokrastinasi akademik) pada pengujian kegiatan pre-test maupun post-test baik kelas kontrol maupun kelas eksperimen menunjukan nilai signifikansi kurang dari 0,05 (Sig. <0,05) sehingga dapat disimpulkan untuk hasil sebaran data pada semua variabel terkait, baik pre-test (kelas kontrol dan eksperimen) maupun post-test (kelas kontrol dan eksperimen) tidak berdistribusi normal.

b. Sedangkan untuk pengujian homogenitas dari hasil data pre-test dan post-test kelompok eksperimen maupun kelompok kontrol dapat diterima jika memiliki nilai signifikansi lebih besar atau sama dengan 5\% (Sig. $\geq 0,05)$, yang berarti bahwa data pre-test dan post-test kedua kelompok tersebut homogen, sehingga memenuhi syarat untuk dilakukan Uji Hipotesis Nonparametric (uji Mann Whitney), berdasarkan dari hasil sebaran data yang tidak berdistribusi normal. Hasil uji homogenitas menunjukkan adanya variabel penelitian yang homogen dan ada yang tidak bervariansi homogen. Variabel penelitian yang memiliki nilai signifikansi lebih dari atau sama dengan $5 \%($ Sig. $\geq 0,05)$ yang berarti data bervariansi homogen adalah kelompok eksperimen maupun kelompok kontrol pada self-control, kelompok eksperimen maupun kelompok kontrol pada selfesteem, dan kelompok kontrol pada self-efficacy. Sedangkan, pada variabel penelitian yang memiliki nilai signifikasi kurang dari 5\% \% (Sig.<0,05) yang berarti data tidak bervariansi homogen ada pada kelompok eksperimen selfefficacy.

\section{Uji Hipotesis Statistik}

a. Berdasarkan hasil uji asumsi statistik pada uji normalitas pada data self-control terkait prokrastinasi akademik yang dilakukan oleh kelas eksperimen diperoleh hasil bahwa data tidak berdistribusi normal. Sedangkan hasil uji homogenitas pada data self-control terkait prokrastinasi akademik yang dilakukan oleh kelas eksperimen diperoleh hasil bahwa data bervariansi homogen.

Dari apa yang sudah didapatkan pada hasil uji di atas, maka uji hipotesis pada data self-control terkait prokrastinasi akademik yang dilakukan oleh kelas eksperimen menggunakan uji non-parametrik, yaitu uji Mann Whitney. Berikut 
adalah hasil olah data uji Mann Whitney menggunakan SPSS terhadap data kelas eksperimen self-control dan prokrastinasi akademik dengan taraf signifikan 0,05 .

Tabel 13. Hasil Uji Mann Whitney pada Kelas Eksperimen Self-Control terhadap Prokrastinasi Akademik

\begin{tabular}{|c|c|c|c|c|}
\hline & Null Hypothesis & Test & Sig. & Decision \\
\hline 1 & $\begin{array}{l}\text { The medians of } \\
\text { Ekperimen Self Control are the } \\
\text { same across categories of terhadap } \\
\text { prokrastinasi akademik sebelum } \\
\text { dan setelah terapi digital pada kelas } \\
\text { eksperimen. }\end{array}$ & $\begin{array}{l}\text { Independent- } \\
\text { Samples } \\
\text { Median Test }\end{array}$ & .000 & $\begin{array}{l}\text { Reject the } \\
\text { null } \\
\text { hypothesis. }\end{array}$ \\
\hline 2 & $\begin{array}{l}\text { The distribution of } \\
\text { Ekperimen Self Control is the } \\
\text { same across categories of terhadap } \\
\text { prokrastinasi akademik sebelum } \\
\text { dan setelah terapi digital pada kelas } \\
\text { eksperimen. }\end{array}$ & $\begin{array}{l}\text { Independent- } \\
\text { Samples Mann- } \\
\text { Whitney U Test }\end{array}$ & .000 & $\begin{array}{l}\text { Reject the } \\
\text { null } \\
\text { hypothesis. }\end{array}$ \\
\hline
\end{tabular}

Berdasarkan tabel di atas nilai Sig.(2-tailed) $=0,000<\alpha=0,05$ artinya $\mathrm{H} 0$ ditolak. Sehingga dapat disimpulkan bahwa Ada pengaruh yang signifikan secara parsial pada kelas eksperimen self-control mahasiswa yang sedang melaksanakan tugas akhir dan skripsi setelah melakukan terapi afektif media digital terhadap prokrastinasi akademik di era pandemic covid-19.

b. Dari apa yang sudah didapatkan pada hasil uji di atas, maka uji hipotesis pada data self-control terkait prokrastinasi akademik yang dilakukan oleh kelas kontrol menggunakan uji non-parametrik, yaitu uji Mann Whitney. Berikut adalah hasil olah data uji Mann Whitney menggunakan SPSS terhadap data kelas kontrol self-control dan prokrastinasi akademik dengan taraf signifikan 0,05.

Tabel 14. Hasil Uji Mann Whitney pada Kelas Kontrol Self-Control terhadap Prokrastinasi Akademik

\begin{tabular}{|c|c|c|c|c|}
\hline & Null Hypothesis & Test & Sig. & Decision \\
\hline 1 & $\begin{array}{l}\text { The medians of } \\
\text { Kontrol Self Control are the same } \\
\text { across categories of terhadap } \\
\text { prokrastinasiakademik sebelum } \\
\text { dan setelah terapi digital pada kelas } \\
\text { kontrol. }\end{array}$ & $\begin{array}{l}\text { Independent- } \\
\text { Samples } \\
\text { Median Test }\end{array}$ & .654 & $\begin{array}{l}\text { Retain the } \\
\text { null } \\
\text { hypothesis. }\end{array}$ \\
\hline 2 & $\begin{array}{l}\text { The distribution of } \\
\text { Kontrol Self Control is the same } \\
\text { across categories of terhadap } \\
\text { prokrastinasiakademiks abelum } \\
\text { dan setelah terapi digital padakelas } \\
\text { kontrol. }\end{array}$ & $\begin{array}{l}\text { Independent- } \\
\text { Samples Mann- } \\
\text { Whitney U Test }\end{array}$ & .795 & $\begin{array}{l}\text { Retain the } \\
\text { null } \\
\text { hypothesis. }\end{array}$ \\
\hline
\end{tabular}

Berdasarkan tabel di atas nilai Sig. (2-tailed) $=0,795>\alpha=0,05$ artinya H0 diterima. Sehingga dapat disimpulkan bahwa Tidak ada pengaruh yang 
signifikan secara parsial pada kelas kontrol self-control mahasiswa yang sedang melaksanakan tugas akhir dan skripsi terhadap prokrastinasi akademik di era pandemic covid-19.

c. Dari apa yang sudah didapatkan pada hasil uji di atas, maka uji hipotesis pada data self-esteem terkait prokrastinasi akademik yang dilakukan oleh kelas eksperimen menggunakan uji non-parametrik, yaitu uji Mann Whitney. Berikut adalah hasil olah data uji Mann Whitney menggunakan SPSS terhadap data kelas eksperimen self-esteem dan prokrastinasi akademik dengan taraf signifikan 0,05.

Tabel 15. Hasil Uji Mann Whitney pada Kelas Eksperimen Self-Esteem terhadap Prokrastinasi Akademik

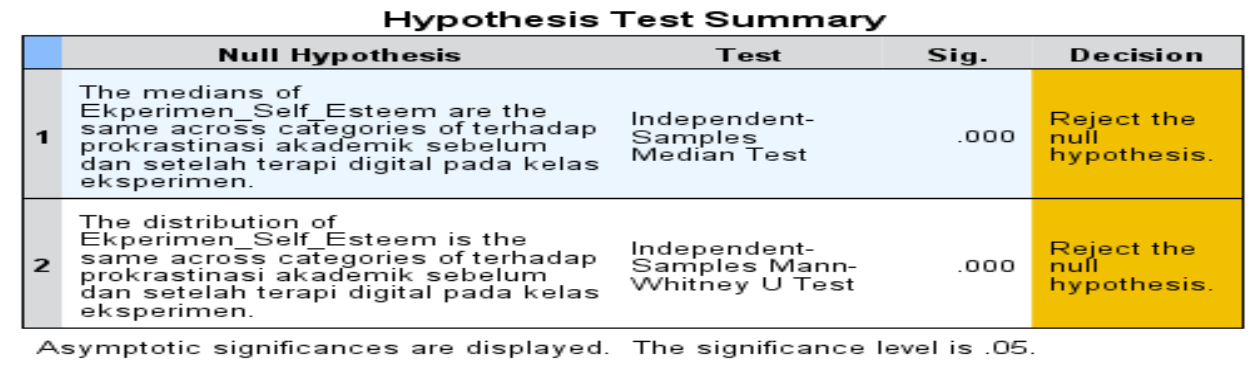

Berdasarkan tabel di atas nilai Sig. (2-tailed) $=0,000<\alpha=0,05$ artinya H0 ditolak. Sehingga dapat disimpulkan bahwa Ada pengaruh yang signifikan secara parsial pada kelas eksperimen self-esteem mahasiswa yang sedang melaksanakan tugas akhir dan skripsi setelah melakukan terapi afektif media digital terhadap prokrastinasi akademik di era pandemic covid-19.

d. Dari apa yang sudah didapatkan pada hasil uji di atas, maka uji hipotesis pada data self-esteem terkait prokrastinasi akademik yang dilakukan oleh kelas kontrol menggunakan uji non-parametrik, yaitu uji Mann Whitney. Berikut adalah hasil olah data uji Mann Whitney menggunakan SPSS terhadap data kelas kontrol self-esteem dan prokrastinasi akademik dengan taraf signifikan 0,05.

Tabel 16. Hasil Uji Mann Whitney pada Kelas Kontrol Self-Esteem terhadap Prokrastinasi Akademik 
Hypothesis Test Summary

\begin{tabular}{|c|c|c|c|c|}
\hline & Null Hypothesis & Test & sig. & Decision \\
\hline 1 & $\begin{array}{l}\text { The medians of } \\
\text { Kontrol_Self Esteem are the same } \\
\text { across categories of terhadap } \\
\text { prokrastinasi akademik sebelum } \\
\text { dan setelah terapi digital pada kelas } \\
\text { kontrol. }\end{array}$ & $\begin{array}{l}\text { Independent- } \\
\text { Samples } \\
\text { Median Test }\end{array}$ & .314 & $\begin{array}{l}\text { Retain the } \\
\text { null } \\
\text { hypothesis. }\end{array}$ \\
\hline 2 & $\begin{array}{l}\text { The distribution of } \\
\text { Kontrol_Self Esteem is the same } \\
\text { across categories of terhadap } \\
\text { prokrastinasiakademik sebelum } \\
\text { dan setelah terapi digital pada kelas } \\
\text { kontrol. }\end{array}$ & $\begin{array}{l}\text { Independent- } \\
\text { Samples Mann- } \\
\text { Whitney U Test }\end{array}$ & .437 & $\begin{array}{l}\text { Retain the } \\
\text { null } \\
\text { hypothesis. }\end{array}$ \\
\hline
\end{tabular}

Berdasarkan tabel di atas nilai Sig.(2-tailed) $=0,437>\alpha=0,05$ artinya H0 diterima. Sehingga dapat disimpulkan bahwa Tidak ada pengaruh yang signifikan secara parsial pada kelas kontrol self-esteem mahasiswa yang sedang melaksanakan tugas akhir dan skripsi terhadap prokrastinasi akademik di era pandemic covid-19.

e. Dari apa yang sudah didapatkan pada hasil uji di atas, maka uji hipotesis pada data self-efficacy terkait prokrastinasi akademik yang dilakukan oleh kelas eksperimen menggunakan uji non-parametrik, yaitu uji Mann Whitney. Berikut adalah hasil olah data uji Mann Whitney menggunakan SPSS terhadap data kelas eksperimen self-efficacy dan prokrastinasi akademik dengan taraf signifikan 0,05 .

Tabel 17. Hasil Uji Mann Whitney pada Kelas Eksperimen Self-Efficacy terhadap Prokrastinasi Akademik

Hypothesis Test Summary

\begin{tabular}{|c|c|c|c|c|}
\hline & Null Hypothesis & Test & Sig. & Decision \\
\hline 1 & $\begin{array}{l}\text { The medians of } \\
\text { Ekperimen_Self_Efficacy are the } \\
\text { same across categories of terhadap } \\
\text { prokrastinasi akademik sebelum } \\
\text { dan setelah terapi digital pada kelas } \\
\text { eksperimen. }\end{array}$ & $\begin{array}{l}\text { Independent- } \\
\text { Samples } \\
\text { Median Test }\end{array}$ & .042 & $\begin{array}{l}\text { Reject the } \\
\text { null } \\
\text { hypothesis. }\end{array}$ \\
\hline 2 & $\begin{array}{l}\text { The distribution of } \\
\text { Ekperimen_Self_Efficacy is the } \\
\text { same across categories of terhadap } \\
\text { prokrastinasi akademik sebelum } \\
\text { dan setelah terapi digital pada kelas } \\
\text { eksperimen. }\end{array}$ & $\begin{array}{l}\text { Independent- } \\
\text { Samples Mann- } \\
\text { Whitney U Test }\end{array}$ & .032 & $\begin{array}{l}\text { Reject the } \\
\text { null } \\
\text { hypothesis. }\end{array}$ \\
\hline
\end{tabular}

Asymptotic significances are displayed. The significance level is .05.

Berdasarkan tabel di atas nilai Sig. $(2$-tailed $)=0,032<\alpha=0,05$ artinya $\mathrm{H} 0$ ditolak. Sehingga dapat disimpulkan bahwa Ada pengaruh yang signifikan 
secara parsial pada kelas eksperimen self-efficacy mahasiswa yang sedang melaksanakan tugas akhir dan skripsi setelah melakukan terapi afektif media digital terhadap prokrastinasi akademik di era pandemic covid-19.

f. Dari apa yang sudah didapatkan pada hasil uji di atas, maka uji hipotesis pada data self-efficacy terkait prokrastinasi akademik yang dilakukan oleh kelas kontrol menggunakan uji non-parametrik, yaitu uji Mann. Berikut adalah hasil olah data uji Mann Whitney menggunakan SPSS terhadap data kelas kontrol self-efficacy dan prokrastinasi akademik dengan taraf signifikan 0,05.

Tabel 17. Hasil Uji Mann Whitney pada Kelas Kontrol Self-Efficacy terhadap Prokrastinasi Akademik

\begin{tabular}{|c|c|c|c|c|}
\hline & Null Hypothesis & Test & Sig. & Decision \\
\hline 1 & $\begin{array}{l}\text { The medians of } \\
\text { Kontrol_Self_Efficacy are the same } \\
\text { across categories of terhadap } \\
\text { prokrastinasi akademik sebelum } \\
\text { dan setelah terapi digital pada kelas } \\
\text { kontrol. }\end{array}$ & $\begin{array}{l}\text { Independent- } \\
\text { Samples } \\
\text { Median Test }\end{array}$ & .911 & $\begin{array}{l}\text { Retain the } \\
\text { null } \\
\text { hypothesis. }\end{array}$ \\
\hline 2 & $\begin{array}{l}\text { The distribution of } \\
\text { Kontrol_Self_Efficacy is the same } \\
\text { across categories of terhadap } \\
\text { prokrastinasi akademik sebelum } \\
\text { dan setelah terapi digital pada kelas } \\
\text { kontrol. }\end{array}$ & $\begin{array}{l}\text { Independent- } \\
\text { Samples Mann- } \\
\text { Whitney U Test }\end{array}$ & .592 & $\begin{array}{l}\text { Retain the } \\
\text { null } \\
\text { hypothesis. }\end{array}$ \\
\hline
\end{tabular}

Berdasarkan tabel di atas nilai Sig. $(2$-tailed $)=0,592>\alpha=0,05$ artinya H0 diterima. Sehingga dapat disimpulkan bahwa Tidak ada pengaruh yang signifikan secara parsial pada kelas kontrol self-efficacy mahasiswa yang sedang melaksanakan tugas akhir dan skripsi terhadap prokrastinasi akademik di era pandemic covid-19.

\section{Pembahasan}

Dari hasil penelitian yang telah dilakukan oleh peneliti, banyaknya faktor yang dapat menyebabkan seseorang tidak bergegas dalam menyelesaikan tugasnya terlebih pada tugas akhir maupun skripsi yang hingga saat ini masih menjadi syarat wajib dalam menyelesaikan jenjang pendidikan tinggi (Menristekdikti, 2015). Tugas akhir maupun skripsi dalam proses penyelesaiannya menuntut mahasiswa agar dapat bertanggungjawab, disiplin, tekun, dan konsisten, namun faktanya tidak sedikit pula mahasiswa yang tidak dapat memanfaatkan waktunya dengan baik 
bahkan hasil dari penelitian terdahulu menyebutkan adanya rasa malas dan kurang motivasi yang dialami oleh mahasiswa pada saat mengerjakan skripsi (Etika et al., 2016). Berangkat dari permasalahan tersebut akhirnya terfokus pada kegiatan prokrastinasi akademik yang dilakukan oleh mahasiswa terutama pada tipe tugas yang membutuhkan tingkat kemandirian tinggi, seperti tugas akhir maupun skrpsi. Menurut Solomon dan Rothblum prokrastinasi sendiri merupakan suatu kecenderungan perilaku menunda-nunda baik untuk memulai maupun menyelesaikan kinerja secara keseluruhan dengan melakukan aktivitas lain yang tidak berguna, sehingga kinerja menjadi terhambat, tidak pernah menyelesaikan tugas tepat waktu, serta sering terlambat dalam menghadiri pertemuanpertemuan(Alwisol, 2012). Sedangkan prokrastinasi akademik ialah prokrastinasi yang terjadi pada area akademik, dimana skripsi merupakan salah satu area akademik terpenting karena menjadi salah satu syarat bagi mahasiswa untuk memperoleh gelar S1(Ursia et al., 2013).

Solusi yang dihadirkan oleh peneliti adalah berusaha menguatkan faktor internal yang ada di dalam diri setiap mahasiswa agar dapat percaya diri, yakin, dan mampu untuk dapat menyelesaikan skripsi tersebut. Adapun hasil penelitian yang diperoleh, bahwa self-control, self-esteem, dan self-efficacy masing-masing berpengaruh secara parsial terhadap prokrastinasi akademik yang dilakukan oleh mahasiswa pada saat sedang melaksanakan tugas akhir maupun skripsi. Artinya, bahwa dari self-control, self-esteem, dan self-efficacy apabila salah satunya ditingkatkan memiliki peran yang signifikan terhadap prokrastinasi akademik. Hal ini sesuai dengan apa yang diutarakan oleh Janssen dan Carton(Ursia et al., 2013) bahwa tingginya kecenderungan prokrastinasi berkaitan dengan rendahnya selfcontrol, self-consciousness, self-esteem, dan self-efficacy, serta adanya kecemasan sosial. Bahkan dari hasil penelitian terdahulu juga menyebutkan mahasiswa yang memiliki self-control tinggi akan mengerjakan tugasnya sesuai waktu yang telah direncanakan(Azalia et al., 2019), begitu juga dengan hasil penelitian terdahulu yang menyebutkan semakin tinggi tingkat self-esteem dan self efficacy seseorang maka akan semakin rendah tindakan prokrastinasi yang akan dilakukan (Khotimah et al., 2016), begitupun sebaliknya. 
Pada self-control dimensi yang diukur adalah Self-discipline, Deliberate/nonimpulsive, Healty habits, Work ethic, dan Reliability(Ursia et al., 2013). Pada self-esteem dimensi yang diukur adalah kekuatan (power), keberartian (significance), kebijakan (viture) dan kompetensi (competence)(Putrisari et al., 2017). Pada self-efficacy dimensi yang diukur adalah magnitude/level, strength, dan generality(Ghufron \& Rini, 2010). Baik dari dimensi-dimensi yang yang ada di self-control, self esteem, dan self-efficacy kesemuanya dikemas menjadi suatu konten terapi afektif digital yang dikembangkan melalui pendekatan terapi realita yaitu The WDEP System (wants, direction \& doing, evaluation, planing)(Adiputra \& Wahyu NES, 2015). Pembeda pada penelitian ini ialah adanya pemanfaatan media digital sebagai alat terapi afektif untuk menguatkan self-control, self-esteem, dan self-efficacy pada mahasiswa yang sedang melaksanakan tugas akhir dan skripsi, yang artinya tidak hanya mendukung tetapi juga menyempurnakan penelitian sebelumnya. Hasil dari penelitian ini membuktikan melalui terapi afektif media digital dapat memberikan pengaruh yang signifikan secara parsial pada selfcontrol, self-esteem, dan self-efficacy pada mahasiswa yang sedang melaksanakan tugas akhir dan skripsi terhadap prokrastinasi akademik.

\section{KESIMPULAN}

Berdasarkan hasil uji hipotesis statistik yang telah dilakukan pada penelitan ini disimpulkan bahwa:

a. Ada pengaruh yang signifikan secara parsial pada kelas eksperimen self-control mahasiswa yang sedang melaksanakan tugas akhir dan skripsi setelah melakukan terapi afektif media digital terhadap prokrastinasi akademik di era pandemic covid-19.

b. Ada pengaruh yang signifikan secara parsial pada kelas eksperimen self-esteem mahasiswa yang sedang melaksanakan tugas akhir dan skripsi setelah melakukan terapi afektif media digital terhadap prokrastinasi akademik di era pandemic covid-19.

c. Ada pengaruh yang signifikan secara parsial pada kelas eksperimen self-efficacy mahasiswa yang sedang melaksanakan tugas akhir dan skripsi setelah 
melakukan terapi afektif media digital terhadap prokrastinasi akademik di era pandemic covid-19.

\section{E. ACKNOWLEDGEMENTS:}

Penulis mengucapkan terima kasih kepada Direktorat Riset dan Pengabdian Masyarakat (DRPM), Kemenristek-BRIN yang telah mendanai penelitian ini melalui skema hibah PDP.

\section{REFERENSI}

Adiputra, S. (2016). Teknik WDEP System Dalam Meningkatkan Keterampilan Belajar Siswa Underachiever. Jurnal Fokus Konseling, 2(1), 32-39.

Adiputra, S., \& Wahyu NES. (2015). Teknik Dasar Konseling. AURA Publisher.

Alwisol. (2012). Psikologi Kepribadian. UMM Press.

Arikunto, S. (2010). Prosedur Penelitian Suatu Pendekatan Praktek. Rineka Cipta.

Azalia, N., Rosra, M., \& ... (2019). Hubungan self control dengan prokrastinasi akademik mahasiswa jurusan ilmu pendidikan 2016. ALIBKIN (Jurnal Bimbingan .... http://jurnal.fkip.unila.ac.id/index.php/ALIB/article/view/19457

Etika, Nur, \& Wilda, F. H. (2016). Deskripsi masalah mahasiswa yang sedang menyelesaikan skripsi. KOPASTA: Jurnal Program Studi Bimbingan Konseling, $3(1)$.

Ghufron, M. N., \& Rini, R. S. (2010). Teori-Teori Psikologi. Ar-Ruzz Media.

Khotimah, R., Radjah, C., \& Handarini, D. (2016). Hubungan Antara Konsep Diri Akademik, Efikasi Diri Akademik, Harga Diri Dan Prokrastinasi Akademik Pada Siswa Smp Negeri Di Kota Malang. Jurnal Kajian Bimbingan Dan Konseling, 1(2), 60-67. https://doi.org/10.17977/um001v1i22016p060

Menristekdikti. (2015). Peraturan Menteri Riset, Teknologi, dan Pendidikan Tinggi Republik Indonesia Nomor 44 Tahun 2015 Tentang Standar Nasional Pendidikan Tinggi. In Current Science.

Pakpahan, R., \& Fitriani, Y. (2020). Analisa Pemafaatan Teknologi Informasi Dalam Pemeblajaran Jarak Jauh Di Tengah Pandemi Virus Corona Covid-19. JISAMAR (Journal of Information System, Applied, Management, Accounting and Researh), $\quad 4(2)$ 30-36. http://journal.stmikjayakarta.ac.id/index.php/jisamar/article/view/181/144

Putrisari, F., Hambali, I. M., \& Handarini, D. M. (2017). Hubungan self-efficacy, selfesteem dan perilaku prokrastinasi siswa madrasah aliyah negeri di Malang Raya. 1(1), 60-68.

Simatupang, N., Sitohang, S., Situmorang, A., \& Simatupang, I. (2020). Efektivitas Pelaksanaan Pengajaran Online Pada Masa Pandemi Covid-19 Dengan Metode 
Survey Sederhana. Jurnal Dinamika Pendidikan, 13(2), 197-203. http://repository.uki.ac.id/2595/2/DokumenJDP0720.pdf

Srisayekti, W., \& Setiady, D. A. (2015). Harga-diri (Self-esteem) Terancam dan Perilaku Menghindar. Jurnal Psikologi, 42(2), 141. https://doi.org/10.22146/jpsi.7169

Sugiyono. (2009). Metode Penelitian Pendidikan. Alfabeta.

Ursia, N. R., Siaputra, I. B., \& Sutanto, N. (2013). Academic Procrastination and SelfControl in Thesis Writing Students of Faculty of Psychology, Universitas Surabaya. Makara Human Behavior Studies in Asia, 17(1), 1. https://doi.org/10.7454/mssh.v17i1.1798 